Jurnal Penelitian Perawat Profesional

Volume 1 Nomor 1, November 2019

p-ISSN 2714-9757

http://jurnal.globalhealthsciencegroup.com/index.php/JPPP

\title{
PENGARUH PEMBERIAN KEDELAI TERHADAP SISTEM REPRODUKSI
}

\author{
Rizky Aprilia Wikayanti*, Andre Parmonangan Panjaitan \\ Program Studi Pendidikan Dokter Universitas Lampung, Jl. Prof. Dr. Ir. Sumantri Brojonegoro No.1, Gedong \\ Meneng, Kec. Rajabasa, Kota Bandar Lampung, Lampung, Indonesia 35145 \\ *apriliarizkywikayanti@gmail.com (+6282179979589)
}

\begin{abstract}
ABSTRAK
Kedelai merupakan tanaman Leguminoceae, yang mengandung senyawa isoflavon. Struktur kimianya menyerupai $17 \beta$-estradiol yang memiliki kemampuan untuk berikatan dengan reseptor estrogen yang dapat berpengaruh terhadap sistem reproduksi manusia. Tujuan literatur review ini untuk mengetahui efek kedelai terhadap sistem reproduksi manusia. Metode yang digunakan adalah metode literatur review dari 50 artikel PubMed NCBI, Elsevier dan BMJ Journal yang diperoleh hanya 38 artikel yang digumakan dari tahun 2000 sampai dengan tahun 2018. Berbagai penelitian eksperimental yang dilakukan menunjukkan bahwa kedelai memiliki efek terhadap sistem reproduksi manusia. Kedelai dapat menyebabkan sekresi FSH, sekresi LH menurun dan meningkatkan konsentrasi estradiol bebas. Penurunan FSH dan LH dapat menyebabkan gangguan dalam siklus menstruasi terutama pada fase folikular dan ovulasi, jika fase folikular terganggu maka siklus menstruasi akan menjadi tidak teratur. Selain itu fitoestrogen yang terkandung dalam kedelai diketahui dapat menghambat 17- $\beta$ hidroksisteroidoksidoreduktase sehingga mengakibatkan penurunan kadar testosteron.
\end{abstract}

Kata kunci: kedelai, reproduksi

\section{THE ROLE OF SOYBEAN FOR REPRODUCTIVE SYSTEM}

\begin{abstract}
Soybean is a Leguminoceae plant, which contains isoflavone compounds. Its chemical structure resembles $17 \beta$-estradiol which has ability to bind to estrogen receptors which can affect the human reproductive system. The purpose of this review literature is to determine the effect of soy on the human reproductive system. Using research articles and books related to the effect of soy on the reproductive system from 2000 to 2018. Various experimental studies conducted showed that soy has an effect on the human reproductive system. Soy can cause FSH secretion, decreased LH secretion and increasing the free concentration of estradiol. Decreased FSH and LH can cause disruption in the menstrual cycle, especially in the follicular phase and ovulation, if the follicular phase is disrupted then the menstrual cycle will become irregular. In addition, phytoestrogens contained in soy are known to inhibit 17- $\beta$ hydroxysteroidoxidoreductase, resulting in a decrease in testosterone levels.
\end{abstract}

Keywords : soybean, reproductive

\section{PENDAHULUAN}

Kedelai adalah tanaman polong-polongan yang banyak dijumpai di beberapa negara dan sudah dimanfaatkan dalam menu makanan sehari-hari karena salah satu tanaman yang murah, mudah diperoleh, dan dapat diolah menjadi berbagai produk yang bercita-rasa dan bergizi tinggi (Aldillah, 2014). Ketersediaan kedelai di Indonesia secara rata-rata pada periode 1993-2016 adalah 9,07 kg/kapita/tahun, pada periode ini ketersediaan kedelai tumbuh sekitar $1,67 \%$ setiap tahunnya. Produksi kedelai yang cukup melimpah di Indonesia menimbulkan daya konsumsi masyarakat. Kedelai dikonsumsi dalam bentuk kue kedelai, kacang goreng, susu kedelai, tepung kedelai dan minyak kedelai, serta dalam banyak bentuk lainnya, baik hanya kedelai atau dalam kombinasi dengan produk makanan lain untuk manusia dan 
sebagai pakan ternak (Whitten dan Patisaul, 2001).

Kandungan kedelai yaitu protein, vitamin, mineral, dan isoflavon (fitoesterogen) diketahui memiliki efek yang positif bagi kesehatan tubuh dan menjadikan kedelai sebagai salah satu sumber protein nabati utama di Indonesia. Namun, beberapa penelitian menyebutkan bahwa mengkonsumsi kedelai dapat membuat konsentrasi semen yang rendah, kualitas semen yang buruk, kurangnya motilitas sperma dan akhirnya libido berkurang (Derosa, Nikov dan Castle, 2006). Selain itu, penelitian Cawood et al., (2001) menunjukkan bahwa pemberian kedelai dapat mengakibatkan cacat reproduksi dan infertilitas (Cawood et al, 2001). Menurut Hess (2003) dan Glover-Assinder (2006) pemberian kedelai mengakibatkan distorsi dalam kesuburan mamalia jantan sehingga berkorelasi langsung dengan distorsi spermatogenesis yang menyebabkan disfungsi, infertilitas, dan toksisitas reproduksi (Hess, 2003; Glover dan Assinder, 2006). Kedelai merupakan makanan yang dikonsumsi oleh hampir seluruh masyrakat Indonesia yang dapat diolah menjadi tahu dan tempe namun informasi yang lebih mendalam mengenai penggunaannya yang terbatas sehingga perlu dilakukannya studi literatur untuk mengetahui efek kedelai terhadap tubuh. Tujuan literatur review ini untuk mengetahui efek kedelai terhadap sistem reproduksi karena kedelai merupakan makanan yang dikonsumsi oleh hampir seluruh masyarakat Indonesia sehingga dapat memberikan informasi bagi masyarakat luas.

\section{METODE}

Penulisan ini menggunakan metode yang digunakan adalah metode literatur review dari 50 artikel PubMed NCBI, Elsevier dan BMJ Journal yang diperoleh hanya 38 artikel yang digunakan terkait ilmu reproduksi manusia dan manfaat kedelai yang menggunakan penelitian-penelitian terbaru dengan proses pencarian artikel database. Tahun penerbitan artikel yang digunakan adalah tahun 2000 sampai tahun 2018. Jumlah artikel yang digunakan ada 38 artikel.

\section{HASIL}

Penelitian menunjukkan bahwa terdapat efek terhadap sistem reproduksi seperti penelitian Rahmi (2007) terhadap spermatogenesis mencit jantan strain balb/c didapatkan penurunan spermatogenesis oleh defisiensi testosteron yang ditimbulkan kedelai. Testosteron merupakan hormon utama yang diproduksi oleh sel leydig sebagai hasil rangsangan dari Luteinizing Hormon (LH) dari hipofisis anterior, yang sangat dibutuhkan dalam spermatogenesis yang berfungsi mengontrol spermatogenesis pada pembelahan meiosis dan juga spermiogenesis. Penurunan kadar testosteron tentunya akan mengganggu spermatogenesis (Greenspan dan Baxter, 2010; Rahmi, 2007). Penelitian oleh Assinder et al., (2005), di New Zealand menunjukkan bahwa fitoestrogen dapat meningkatkan apoptosis pada sel benih (sel calon spermatogenik) \& menurunkan produksi sperma. Penelitian oleh Nagata et al., (2001) membuktikan bahwa susunan kimia kedelai memiliki pengaruh pada kesehatan reproduksi pria termasuk menurunkan berat kelenjar prostat, menurunkan kadar testosteron, dan menyebabkan nekrosis dan kematian pada sel testikular secara signifikan (Assinder et al, 2005; dan Nagata et al, 2000).

Penelitian Setchell et al., (2000) menunjukkan bahwa isoflavon menginduksi abnormalitas sistem reproduksi jantan (Setchell et al, 2000). Hal ini diperkuat dengan penelitian Chevarro et al., (2008) yang menunjukkan bahwa isoflavon yang diberikan per oral pada manusia dapat menurunkan konsentrasi sperma (Chevarro et al, 2008). Selain itu, penelitian yang dilakukan oleh Cardoso et al., (2007) menyatakan bahwa isoflavon yang diberikan dengan dosis $2,5 \mathrm{mg} / \mathrm{kg}$ dan 10 
$\mathrm{mg} / \mathrm{kg}$ dapat menurunkan volume semen pada kelinci (Cardoso et al, 2007). Penelitian yang telah dilakukan oleh Kuntana (2009) menunjukkan bahwa pemberian ekstrak kedelai dapat menurunkan kualitas sperma pada kelinci (Oryctolagus cuniculus) (Kuntana, 2009). Penelitian Adeeyo et al., (2011) menunjukkan bahwa tepung kedelai berpengaruh terhadap berat testis, motilitas dan viabilitas sperma, kadar testosteron serta abnormalitas morfologi sperma yang meliputi kaput, dan ekor sperma (Adeeyo $e t$ $a l, 2011)$.

Penelitian yang dilakukan An et al., (2018) di Chungbuk National University, Korea terhadap tikus betina dan jantan yang dikawinkan dan diamati selama masa gestasional, laktasional, dan perkembangan sistem reproduksi. Pemberian susu kedelai tidak mempengaruhi kelahiran dan perkembangan fisik anak laki-laki dan perempuan. Penilaian sistem reproduksi terhadap tikus jantan didapatkan bobot testis dan epididimida meningkat secara signifikan dengan memberi makan susu kedelai konsentrasi tinggi. Selain itu, pemberian susu kedelai juga meningkatkan jumlah dan motilitas sperma. Sehingga, susu kedelai aman untuk embrio, janin, keturunan, dan meningkatkan perkembangan fungsi reproduksi (An $e t a l$, 2018).

\section{PEMBAHASAN}

Kedelai adalah jenis tanaman Leguminoceae, yang sudah dikenal dan sering dikonsumsi manusia. Biji, daun, dan bunganya sering dimanfaatkan dan dijadikan penelitian karena mempunyai sejumlah senyawa yang berperan penting dalam kehidupan manusia. Penelitian menunjukkan bahwa kedelai mempunyai efek terhadap sistem reproduksi manusia (Kementrian Pertanian, 2015). Sistem reproduksi manusia dibagi menjadi dua yaitu sistem reproduksi pria dan wanita. Dalam sistem reproduksi dibagi menjadi (1) spermatogenesis/oogenesis, yang berarti pembentukkan sperma/ovum; (2) kinerja kegiatan seksual pria/wanita; dan (3) pengaturan fungsi reproduksi pria/wanita dengan berbagai hormon (Guyton dan Hall, 2016).

Kedelai sudah banyak diteliti dalam kesehatan tetapi masih sangat sedikit informasi terkait manfaat kedelai sebagai salah satu bahan alam yang dapat mempengaruhi sistem reproduksi manusia. Pernyataan tersebut dibuktikan dengan beberapa hasil penelitian yang sudah dilakukan, dimana menyatakan bahwa biji kedelai mengandung senyawa isoflavon (Pelissero et al, 2000; Delmote dan Rader, 2006). Isoflavon merupakan kelompok flavonoid yang mempunyai aktivitas estrogenik potensial dan strukturnya memiliki kemiripan dengan hormon estrogen. Kandungan senyawa isoflavon pada biji kedelai adalah 9,4 mg (Barlow, Johnson dan Scofield, 2007). Berdasarkan struktur kimianya menyerupai $17 \beta$-estradiol menyebabkan kemampuannya berikatan dengan reseptor estrogen. Fitoestrogen kedelai, seperti genistein atau isoflavon, diketahui dapat menghambat 17- $\beta$ hidroksisteroidoksidoreduktase, enzim yang diperlukan dalam pengubahan androstenodion menjadi testosteron, sehingga pada defisiensi enzim tersebut mengakibatkan penurunan kadar testosteron (Gruber et al, 2000).

Fitoestrogen memiliki kemampuan efek estrogen dan atau efek anti estrogen karena kemiripan strukturnya dengan hormon estradiol yang terdapat pada manusia. Fitoestrogen memunculkan efek anti estrogenik jika berada pada lingkungan dengan konsentrasi estrogen tinggi, dan sebaliknya memunculkan efek estrogenik jika berada di lingkungan dengan konsentrasi estrogen yang rendah. Efek estrogenik ini yang kemudian timbul pada mencit jantan karena rendahnya konsentrasi estrogen. Timbulnya efek estrogenik ini dapat mengakibatkan penurunan androgen. Penurunan androgen ini, menyebabkan 
turunnya kadar testosteron sebagai androgen terbesar yang diproduksi testis, contoh lain akibat peningkatan kadar estrogen pada pria adalah ginekomastia. Konsumsi kedelai yang berlebihan selama masa pertumbuhan dan perkembangan sistem reproduksi pria diketahui dapat mempengaruhi kesuburan saat memasuki masa pubertas. Konsumsi kedelai yang berlebihan dapat mengganggu kualitas sperma. Hal ini berkaitan dengan aktivitas estrogenik dari salah satu kandungan isoflavon yang terdapat pada kedelai sehingga pertumbuhan dan perkembangan sistem reproduksi pria dapat terganggu (Gultekin dan Yildiz, 2006; Akingbemi et al, 2007).

Isoflavon kedelai dapat berikatan dengan RE (Reseptor Estrogen) di hipotalamus mensintesis GnRH (GonadotropinReleasing Hormone) untuk menstimulus sekresi FSH (Follicle Stimulating Hormone) dan LH (Luteinizing Hormone). Hipothalamus dan hipofise mempunyai resptor androgen dan estrogen. Efek inhibisi yang diperantarai oleh estradiol yang dihasilkan dari aromatisasi testosteron dapat menyebabkan sekresi FSH dan sekresi LH menurun. Genistein selain dapat berikatan dengan RE, dapat berikatan secara aktif dengan SHBG (Sex Hormone Binding Globulin), sehingga meningkatkan konsentrasi estradiol bebas. Penurunan FSH dan LH dapat menyebabkan gangguan dalam siklus menstruasi terutama pada fase folikular dan ovulasi, jika fase folikular terganggu maka siklus menstruasi akan menjadi tidak teratur (Koeswara dan Sutrisno, 2006; Drake, 2009).

Strom et al., (2001) menjelaskan perbandingan pemberian susu formula kedelai dan susu sapi formula pada sampel penelitian mengungkapkan bahwa kelompok sampel yang diberikan susu formula kedelai mengalami durasi menstruasi yang lebih panjang selama menstruasi. Mencit betina akan mengalami ovulasi spontan dengan daur estrus, proses endokrin yang mendasari dan siklus di ovarium pada prinsipnya sama seperti proses daur menstruasi sehingga proses menstruasi yang terjadi pada manusia sama hal nya dengan mencit betina. Takaran dosis dan lama waktu mengkonsumsi susu kedelai yang aman dan benar belum diketahui secara pasti (Strom et al., (2001; Ganong, 2014). Pino et al., (2000) menjelaskan aktivitas estrogenik ketika diberikan pada wanita pasca-menopause dengan menunjukkan peningkatan kadar globulin pengikat hormon seks atau SHBG yang berperan dalam mengikat hormon gonad (Pino et al, 2000). Studi terbaru menyimpulkan bahwa isoflavon dapat ditargetkan untuk terapi penggantian hormon pada wanita menopause (Lagari dan Levis, 2014; Poluzzi et al, 2014). Suplementasi sekitar $54 \mathrm{mg}$ isoflavon untuk jangka waktu 8 minggu pada wanita pascamenopause dapat menurunkan kadar hormon perangsang folikel atau FSH dan hormon luteinizing atau LH (Husain et al, 2015).

Isoflavon dilaporkan memberikan efek penyeimbangan pada hormon reproduksi dan fungsi endotelial wanita yang berada di akhir menarche mereka tetapi, tidak ada efek untuk wanita post-menopause. ${ }^{33}$ Namun, menurut Messina et al., (2005) bahwa suplementasi kedelai memberikan efek sebelum adanya gejala menopause (Amato et al, 2005). Suplementasi kedelai dalam 16 minggu dalam bentuk susu kedelai $(71,6 \mathrm{mg}$ isoflavon yang berasal dari $706 \mathrm{~mL}$ susu kedelai/hari) dan isoflavon $(70 \mathrm{mg}$ isoflavon $+706 \mathrm{~mL}$ susu sapi/ hari) meningkatkan kekebalan pada pasca-menopause wanita dengan memodulasi sel B dan perlindungan terhadap kerusakan DNA (Messina et al, 2005; Ryan-Borchers et al, 2006). Wang et al., (2013) menjelaskan bahwa pemberian isoflavon pada tikus betina dapat menimbulkan komplikasi serius pada sistem reproduksi dengan aktivasi berbagai jalur apoptosis. Selain itu, didapatkan penurunan kadar estradiol serum dan peningkatan 
jumlah atresia folikel ovarium dan jumlah korpus luteum (Wang et al, 2013). Menurut Adeeyo et al., (2011) efek antifertilitas dari kacang kedelai yang digunakan dalam pakan/makanan $>8,33 \%$ dari pakan/ makanan. Penelitian lebih lanjut dibutuhkan untuk memverifikasi studi ini, serta derivasi tingkat aman yang lebih tepat dari kacang kedelai juga sangat dibutuhkan (Adeeyo et al, 2011).

\section{SIMPULAN}

Kedelai memiliki pengaruh terhadap sistem reproduksi manusia seperti mengakibatkan penurunan kadar testosteron dan menurunkan kadar androgen tubuh.

\section{DAFTAR PUSTAKA}

Adeeyo, Salawu, Ola, Saka, Adeleke, Adeniyi, OS. (2011). Effects of Soya Beans Supplements on Fertility in Male Wistar Rats. Macedonian Journal of Medical Sciences. 4 (1), 54-59.

Akingbemi BT, Braden TD, Kemppainen BW, Hancock KD, Sherrill JD, Cook SJ, He X, Supko JG. (2007). Exposure to phytoestrogens in the perinatal period affects androgen secretion by testicular Leydig cells in the adult rat. Endocrinology. 148 (1), 4475-4488.

Aldillah, R. (2014). Analisis Produksi Dan Konsumsi Kedelai Nasional [Tesis]. Bogor; Fakultas Kedokteran Institut Pertanian Bogor.

Amato, Young, Steinberg, Murray, Lewis, Cramer et al. (2013). Effect of Soy Isoflavone Supplementation on Menopausal Quality of Life. Menopause. 20 (4), 443-447.

An, Park, Ban, Choi, Seo, Lee et al. (2018). Effects of a soybean milk product on feto-neonatal development in rats. J Biomed Res. 32 (1), 1-57.

Assinder S, Davis R, Fenwick M, Glowver
A. (2005). Endocrine disruption of sperm production in rats by a high phytoestrogen diet. Proceedings of the New Zealand Society of Endocrinology Annual Meeting held as the part of MedSciNZ Congress. Queenstown, New Zealand.

Barlow, Johnson, Scofield. (2007). Fact Sheet on The Phytoestrogen Genistein. NIEHS/NCI Environment Research Center. Diakses dari http://cerhr.niehs.nih.gov/chemicals/g enistein, 8/08/2010.

Cardoso, Mondadori, Bianchini, Nair et al. (2007). Effect of Chronic Treatment with Soy Derived Isoflavones on Reproductive Health of Male Rabbits. Journal Biology Science. 23 (1), 7582.

Cawood, Mitchell, Kinniburgh, Provan, Collins, A.R. and Irvine. (2001). Effect of a phytoestrogens food supplement on reproductive health in normal males. Clinical Science. 100, 613-618.

Chevarro, J.E., Toth, T.L., Sado, S.M., Hauser, R. (2008). Soy Food and Isovlavone Intake in Relation to Semen Quality Parameters Among Men from an Infertility Clinic. Human Reproduction. 23 (1), 2584259.

Colacurci, Chiantera, Fornaro, Novellis, Manzella, Arciello et al. (2013). Effects of Soy Isoflavones on Endothelial Function in Healthy Postmenopausal Women. Menopause. 12 (3), 299-307.

Delmonte dan Rader. (2006). Analysis of Isoflavones in Foods and Dietary Supplements. Journal of AOAC International. 89 (4), 1138-1146.

Derosa, Nikov, and Castle. (2006). Environmental exposures that affect 
the endocrine system: Public Health Implications. Journal of Toxicology and Environmental Health. 1 (2), 2026.

Drake, VJ. (2009). Isoflavones. Linus Pauling Institute. Oregon State University. Diakses dari http://lpi.oregonstate.edu/infocenter/ phytochemicals /soyiso.Ganong, W.F. (2014). Buku Ajar Fisiologi Kedokteran. Jakarta: EGC.

Glover, A. and Assinder, S.J. (2006). Acute exposure of adult male rats to dietary phytoestrogens reduces fecundity and alters epididymal steroid hormone receptor expression. Journal of Endocrinology. 189, 565-573

Greenspan FS, Baxter JD. (2014). Endokrinologi dasar \& klinik, ed 4. Jakarta: EGC..

Gruber, Tschugguel, Schneeberger, Huber. (2000). Production and Actions of Estrogens. The New England Journal of Medicine. 346 (5), 340-352.

Gultekin E, Yildiz F. (2006). Introduction to phytoestrogen. In: Yildiz F, editor. Phytoestrogens in functional foods. Boca Raton: CRC Press Taylor\&Francis Group LLC.

Guyton dan Hall. (2016). Buku Ajar Fisiologi Kedokteran. Edisi 12. Jakarta : EGC.

Hess, R.A. (2003). Estrogen in adult male reproductive tract: A review. Reproductive Biology and Endocrinology. 1, 52-63.

Husain, Khanna, Puri, Haghighizadeh. (2015). Supplementation of Soy Isoflavones Improved Sex Hormones, Blood Pressure, and Postmenopausal Symptoms. Journal of the American College of Nutrition. 34 (1), 1-7.
Karahalil B. (2006). Benefit and risks of phytoestrogen. In: Yildiz F, editor. Phytoestrogens in functional foods. Boca Raton, Florida: CRC Press Taylor\&Francis Group LLC. 1 (2), 210-215.

Kementerian Perindustrian. (2015). Ironi Kedelai Impor di Negeri Tempe. Jakarta: Kemenprin.

Koeswara, Sutrisno. (2006). Isoflavon Senyawa Multi Manfaat Dalam Kedelai. IPB: Bogor.

Kuntana, Y.P. (2009). Pengaruh Pemberian Phytoestrogen Terhadap Kualitas Spermatozoa, Spermatogenesis dan Luas Jaringan Interstitial pada Kelinci (Oryctolagus cuniculus), Jurnal Bionatura. 11 (1), 47-58.

Lagari, Levis. (2014). Phytestrogens for Menopausal Bone Loss and Climacteric Symptoms. The Journal of Steroid Biochemistry and Molecular Biology. 139, 294-301.

Messina, Ho, Alekel. (2004). Skeletal Benefits of Soy Isoflavones: A Review of the Clinical Trial and Epidemiologic Data. Current Opinion in Clinical Nutrition \& Metabolic Care. 7 (6), 649-658.

Nagata, C., Inaba, S., Kawakami, N., Kakizoe, T. \& Shimizu, H. (2000). Inverse association of soy product intake with serum androgen and estrogen concentrations in japanese men. Nutrition and Cancer 36, 14-1

Pelissero, C.B., Latonnelle, K., Sequeira, A., Lamothe. (2000). Phytoestrogens, Endocrine Disrupters from Food. Analusis. 28, 763-776.

Pino, Valladares, Palma, Mancilla, Yáñez, Albala et al. (2000). Dietary Isoflavones Affect Sex HormoneBinding Globulin Levels in 
Postmenopausal Women. The Journal of Clinical Endocrinology and

Metabolism. 85 (8), 2797-2800.

Poluzzi, Piccinni, Raschi, Rampa, Recanatini, De Ponti et al. (2014). Phytestrogens in Postmenopause: The State of the Art from a Chemical, Pharmacological, and Regulatory Perspective. Current Medicinal Chemistry. 21 (4), 417.

Rahmi D. (2007). Pengaruh pemberian ekstrak kedelai pada spermatogenesis mencit jantan strain balb/c [skripsi]. Semarang: $\quad F k \quad$ Universitas Diponegoro.

Ryan-Borchers, Park, Chew, McGuire, Fournier, Beerman et al. (2006). Soy Isoflavones Modulate Immune Function in Healthy Postmenopausal Women. The American Journal of Clinical Nutrition. 83 (5), 11181125 .

Setchell, K, Nechemias, L.Z, Cai, J, Heubi, J. (2000). Isoflavone Content of Instant Formulas and the Metabolic Fate of These Phytoestrogens in Early Life. American Journal Society for Clinical Nutriion. 68, 1453-1461..

Strom, Schinnar, Zieger, Barnhart, Sammel, Macones et al. (2001). Exposure to Soy-based Formula in Infancy and Endocrinological and Reproductive Outcomes in Young Adulthood. JAMA. 286 (7), 807 - 14.

Wang, Zhang, Liu, Sun, Li, Li et al. (2013). Metabolomic Changes in Follicular Fluid Induced by Soy Isoflavones Administered to Rats from Weaning Until Sexual Maturity. Toxicology and Applied Pharmacology. 269 (3), 280-289.

Whitten dan Patisaul (2001). Crossspecies and interassay comparisons of phytoestrogen action. Environment 
Jurnal Penelitian Perawat Profesional, Volume 1 No 1 Hal 53 - 60, November 2019 Global Health Science Group 